\title{
Medical Engineering Education based on the Spiral Approach
}

\author{
http://dx.doi.org/10.3991/ijep.v6i3.5759 \\ Z. Ovadia-Blechman, I. Muller and S. Naftali \\ Afeka Academic College of Engineering, Tel Aviv, Israel
}

\begin{abstract}
The goal of Medical Engineering (ME) education is to qualify students to become engineers who can provide technological solutions to problems encountered in medical environments. The undergraduate program of $\mathrm{ME}$ has been emerging as a distinct discipline at academic institutions. Students in this program undergo extensive training in both medicine and engineering sciences. This manuscript presents the curriculum of the ME bachelor's degree program at Afeka College of Engineering, which is designed according to the spiral approach. This approach is based on iterative revisiting of topics, such that with each encounter, levels of difficulty and sophistication are increased, new learning is related to previous learning, and students' competency is enhanced. A survey of students and graduates indicates that the approach greatly contributes to an integrative understanding of the studied material. Our experience of using this approach suggests that it fosters a holistic perspective and that it provides graduates with skills for dealing with industrial and academy challenges. This manuscript could contribute for anyone who develops or improves curriculum, particularly in a multidisciplinary program.
\end{abstract}

Index Terms-medical engineering, spiral approach, curriculum design, bachelor degree, biomedical engineering education, problem-based learning (PBL), student satisfaction.

\section{INTRODUCTION}

Medical Engineering (ME) is a multidisciplinary field that offers technological solutions to problems of clinical care delivery, general practice, and the feasibility of expanding automation and self- medicine [1]. This field has been gaining prominence in recent years in light of the emergence of new technologies for diagnosis and treatment of diseases. For example, developments such as telemedicine, the miniaturization of sensors, and noninvasive procedures for obtaining information from a patient's body have revolutionized medical practice. In addition, advancements in cell and tissue engineering have led to the production of effective implants, facilitating innovative therapy and advanced research. ME consists of research and development (R\&D) and covers a wide range of subfields such as biomechanics, bioelectronics, biomaterials, medical signal and imaging processing, biosensors, medical communication, tissue engineering, and ethical issues [2].

The undergraduate program of ME has been emerging as a distinct discipline at academic institutions. Students in this program undergo extensive training in both medicine and engineering sciences. The goal of ME curriculum is to train engineers who will be able to provide technological solutions to problems encountered in different medical environments. Previous studies were indicated that institutes in higher education may improve their students' progress to some extent by means of efficient curriculum organization [3], [4], [5]. Therefore, the ME curriculum structure should be challenging and should encourage high-level thinking. The theme of knowledge integration has been already discussed in engineering education literature [6] [7] [8].

Integration of the Problem-Based Learning (PBL) approach, which emphasizes learning through self-studying, was found suitable to improve the learning of engineering education process [3]. Thus, it is important to integrate this tool in the curriculum.

The Conceive Design Implement Operate (CDIO) initiative is based on the principle that product and system lifecycle development and deployment are the appropriate context for engineering education. In an aim to advance engineers' training, the CDIO strives to achieve three overall goals: i) to master a deeper working knowledge of technical fundamentals; ii) to lead in the creation and operation of new products, processes and systems; iii) to understand the societal importance and strategic impact of research and technological development [5], [9]. With the aim of preparing the engineering graduates according to the needs of industry, our institute, Afeka College, has joined the CDIO organization in 2011 and adopted its pedagogical approach.

In the presented program making connections of knowledge in various fields based on the development of skills that require a higher level of thinking, was attained using the spiral approach. The spiral approach is an educational methodology that operates in harmony with a cognitive model and relies on curriculum concepts that Bruner introduced in 1960 [10]. The approach is based upon an iterative revisiting of topics, subjects or themes throughout one's studies. A spiral curriculum is not simply the repetition of a topic taught: It involves deepening students' understanding of each topic through multiple encounters, with each successive encounter building on the previous one. With each encounter, levels of difficulty and sophistication are increased, new learning is related to previous learning, and the students' competency and overall understanding of the studies are enhanced [5], [11], [12]. The spiral method overlaps conceptually with the systemsbased Synthesis and Design Studio (SDS) model presented by Gattie et al. [13]. The SDS model is structured such that each semester comprises traditional academic courses dynamically coupled with Studios, which serve as a largerscale context into which smaller-scale course-level content is mapped. The spiral and SDS approaches create a challenging learning environment for students as well as a challenging teaching environment for lecturers [10].

This manuscript presents in detail the implementation of the spiral method in ME education. 


\section{Curriculum Methodology}

\section{A. ME Education at Afeka College}

The ME bachelor's degree at Afeka - Tel-Aviv Academic College of Engineering is a four-year accredited program (Council for Higher Education in Israel [14]). To graduate, students must accumulate 160 credit points, of which 121 credits are associated with mandatory courses. The program was designed to prepare graduates to provide technological solutions to complex problems arising from diverse medical needs in the industrial world, and to prepare them for advanced education.

The academic staff at the ME department teaches engineering according to the spiral approach, based upon an iterative revisiting of topics. The curriculum aims to develop students' knowledge and skills in engineering science, medical devices, clinical research and medical information systems. The program begins with basic sciences (mathematics, physics and chemistry), which are the scientific foundations for all engineering subjects. Students subsequently proceed to acquire multidisciplinary knowledge comprising elements from the fields of medical physiology and technological engineering.

The program focuses on three fields: The first is mechanics of physiological systems (MPS), which integrates the study of physiological systems with mechanical engineering. This discipline qualifies students to develop new mechanical solutions such as orthopedic implants, synthetic vessel bypasses, catheters and pumps for the cardiovascular system. The second field is digital signal processing and image processing (DSPIP), which focuses on enhancing medical knowledge through a variety of physiological signals and images. DSPIP studies include courses on medical information systems that integrate computer software with medical engineering. The third field is clinical engineering (CE), which provides tools for managing medical technological systems. This field focuses on planning and control of clinical experiments as well as logistical management of new medical products. These three specialization branches of the curriculum are presented in the "Golden Triangle" shown in Fig. 1. The triangle was designed to highlight the practical focus of the ME curriculum. A breakdown of the courses is provided in Table 1.

\section{B. Implementation of the Spiral Approach}

As noted above, the curriculum of the ME bachelor's degree, presented in the previous section, is based on the spiral approach method, which aims to challenge students. Fig. 2 illustrates how the Golden Triangle is reflected in this method, where the right side includes MPS courses, the left side includes DSPIP courses, and the clinical engineering (CE) courses are shown at the center. As shown in Fig. 2, the first year of undergraduate studies includes a basic course called "Introduction to Medical Technology", which exposes the students to the world of medical science and engineering. During the course the students absorb terms used in ME and are exposed to advanced, state-ofthe-art medical technologies. Concurrently, the students participate in basic science courses, including courses in mathematics, physics, chemistry and medicine. Studies in the English language are incorporated into ME courses beginning from the first semester and throughout the years of study. For example, students learn scientific and medical terminology in English and are required to use English in classroom practice sessions, home assignments and

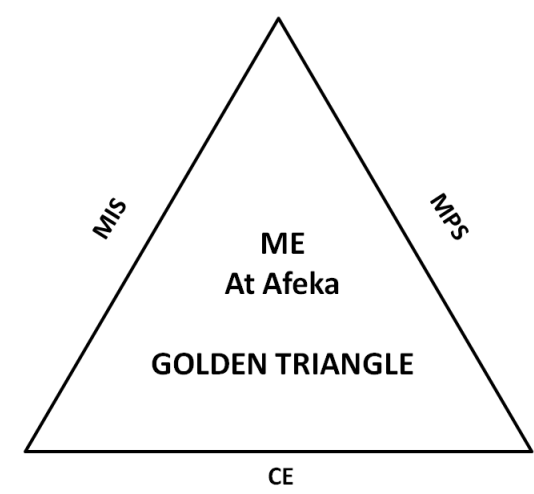

Figure 1. The ME "Golden Triangle".

exams. This emphasis on the English language is necessary in order to provide ME graduates with the skills they will need to perform future professional tasks [15].

During the second year, the curriculum comprises deepen knowledge in mathematics, physics and medicine, in parallel to the fundamental elements of engineering. Key courses at this stage include "Thermodynamics and Heat Transfer", "Fluid Mechanics", "Digital Signal Processing (DSP)", "Image Processing" and "Clinical Engineering and Health Technology Management" (Table 1, "Basic" row).

The syllabus for the third year includes advanced-level courses for each discipline; these courses aim to enhance students' understanding of the topics taught in the previous courses. These advanced courses include "Physiological Mechanics of the Musculoskeletal System", "Heat and Mass Transfer in Biological Systems", "Advanced Flow and Its Medical Application", "Advanced Signal Processing and its Medical Application", "Advanced Applications of Image Processing and its Medical Applications" and "Clinical Trials". In addition, courses such as "General and Systemic Pathology" and "Introduction to Tissue Engineering" provide in-depth physiological knowledge, based on the previous courses in exact sciences, medicine and engineering. This phase of the curriculum increases the depth and complexity of the acquired knowledge, as well as of the tasks assigned to students. To perform the tasks required of them in these advanced courses, students must draw from the knowledge and skills that they have acquired in all studied fields. For example, in the course "Computational Methods in Engineering", students are required to solve physiological problems based on computational simulation, using prior knowledge from fields such as biomechanics, heat transfer and biofluid engineering. Towards the end of the third year, each student chooses a topic for his or her final project in engineering, which will be carried out during the fourth year.

The curriculum for the fourth year is the final step of the spiral program. This year combines content reflecting all the abilities that students have acquired throughout their years in the program and focuses on preparing students for entering the ME industry and for postgraduate education. A course called "Exposure to the Medical Industry and Medical Centers" exposes students to ME practice through weekly visits to medical and industrial centers. The visits include professional lectures and on-site demonstrations of leading technologies and advancements in the ME field. This course is based on the knowledge and experience that students have accumulated throughout their studies. Moreover, students are required to analyze and evaluate tech- 
nologies and needs, from a medical engineer's point of view. In addition, students participate in an ME "Seminar" course in which they carry out a thorough, critical investigation of an ME topic and present it. Following the presentation, a discussion takes place. Students also create a review manuscript by summarizing and editing survey articles. Additionally, as an integral part of their "Material for Medical Engineering and Implants" course, students are divided into teams. They are required to design and present a novel medical device that provides a solution for a medical need. This task includes meeting with professional staff in order to define a topic, performing an extensive literature review, designing the engineering solution, planning the clinical regulation process and assessing the economic feasibility of producing the device. All these steps are based on previous studies in various disciplines. The students who design the top 5 ventures present their work in front of the class, the academic staff and a panel of specialists, which includes investors, industrialists and expert engineers.

Concurrently, students execute the final project of their ME degree, the scope of which is approximately 400 hours. The project is an opportunity to acquire experience in dealing with an entire engineering challenge, independently and creatively, under the guidance of a professional advisor. The students carry out an R\&D assignment in which they must complete a comprehensive engineering design, set milestones for construction of the project, and build a prototype, as is customary in the ME academy or industry. Finally, students are required to participate in a "Medical Ethics" course, as it is important not only to provide engineering experience but also to raise ME students' awareness regarding the ethical issues that ME engineers may encounter throughout their careers.

\section{INTERNAL SURVEY}

A survey was conducted in order to assess students' and graduates' evaluations of the contribution of the spiral approach to their training. The survey was carried out among both graduates students and fourth year students $(\mathrm{N}=40)$. Participants responded to each survey item by rating a scale ranging from 1 to 5 (slight to high degree of contribution, respectively). They also provided additional assessments as free text. The results of this survey show that the students and graduates expressed the retrospective view, that the spiral approach helped them to understand and to internalize the studied material $(4.5 \pm 0.6)$. They also indicated that the course "Exposure to the Medical Industry and Medical Centers" contributed to the implementation of the spiral approach $(4.6 \pm 0.7)$. They emphasized indicated that the approach had greatly contributed to their integrative understanding of the studied material. Furthermore, they stated that during the first year they had been exposed to new terms from various disciplines, and that throughout subsequent years of study, the repetition and the deepening explorations of the topics led them to better understand and apply the studied material.

An internal survey, updated to 2015, indicates that $90 \%$ of the graduates of the Afeka ME department hold engineering positions in a wide variety of $\mathrm{ME}$ fields in the industry as well as in the Israeli Health Ministry. About $10 \%$ of graduates continue on to advanced studies. Furthermore, there are employers who repeatedly recruit new graduates. Here, for example, an assessment of Vice President in ME company: "These graduates have a broad and

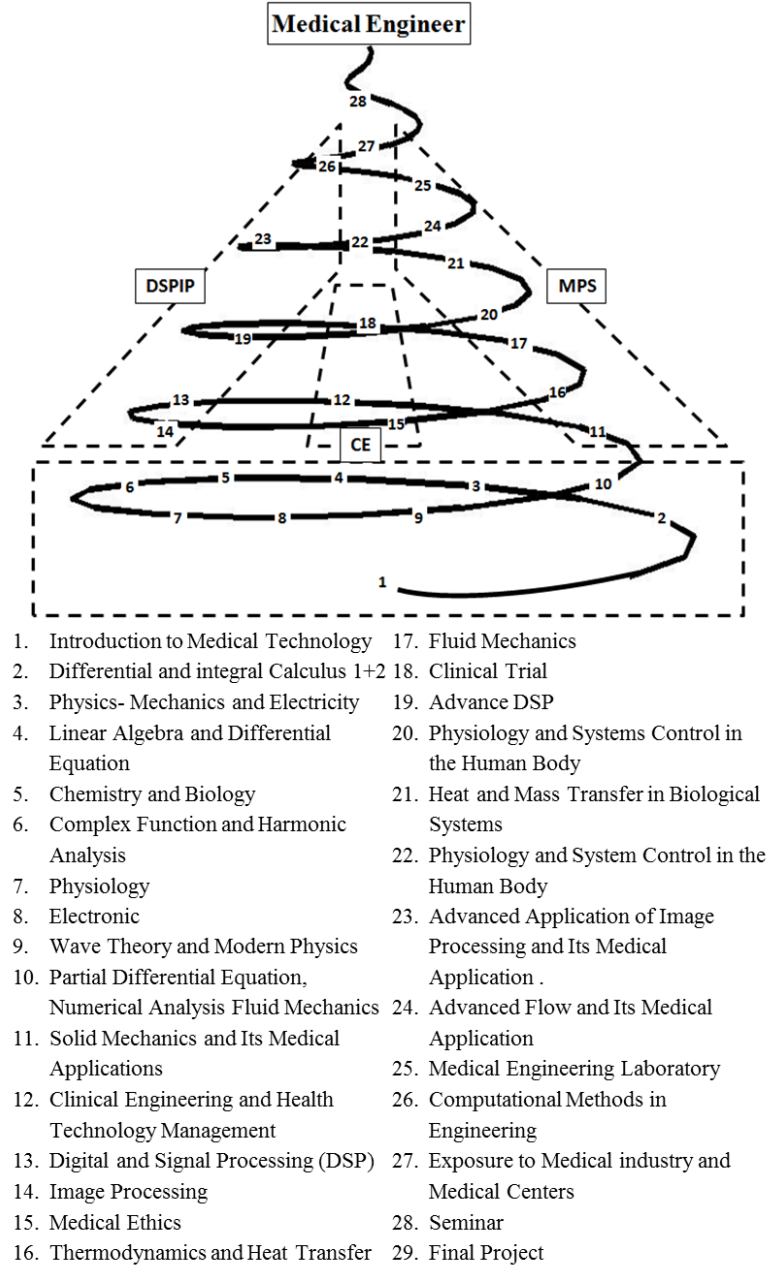

Figure 2. Illustration of the spiral approach as reflected in the ME curriculum.

integrated approach, including linking between various disciplines. They also have practical tools based on theoretical knowledge".

\section{SUMMARY}

An ME curriculum needs to link knowledge from various engineering disciplines (mechanical, electrical, software), as well as from medicine, in order to train creative and open-minded medical engineers. Effective organization of the curriculum leads to improve student achievements [4]. As described above, the spiral approach introduces students to basic subjects at first, and then focuses on more advanced subjects. This methodology is based on high-level thinking that challenges both students and lecturers. Our experience in the ME department at Afeka College suggests that the use of the spiral approach provides students with a holistic perspective and offers them tools for dealing with problems encountered in the industry and in the academic research world. The advanced courses that are offered during the fourth year exemplify the implementation of this approach, since they combine different tasks that integrate skills obtained throughout the entire program: selecting and researching a seminar topic ("Seminar"), designing a medical device that can be feasibly produced ("Material for Medical Engineering and Implants"), and writing feedback reports about innovative medical technologies ("Exposure to the Medical Industry 
PAPER

MedicAl ENGineERING EduCATION BASEd ON THE SPIRAL APPROACH

TABLE I.

A Breakdown Of The ME Program At Afeka College

\begin{tabular}{|c|c|c|c|c|c|}
\hline & \multicolumn{5}{|c|}{ - $\quad$ Introduction for Medical Engineering (0.5) } \\
\hline & \multicolumn{2}{|l|}{ Basic Science } & \multicolumn{3}{|c|}{ Medical Engineering } \\
\hline & Exact Science & Medical Science & MPS & MIS & $\mathbf{C E}$ \\
\hline Basic & 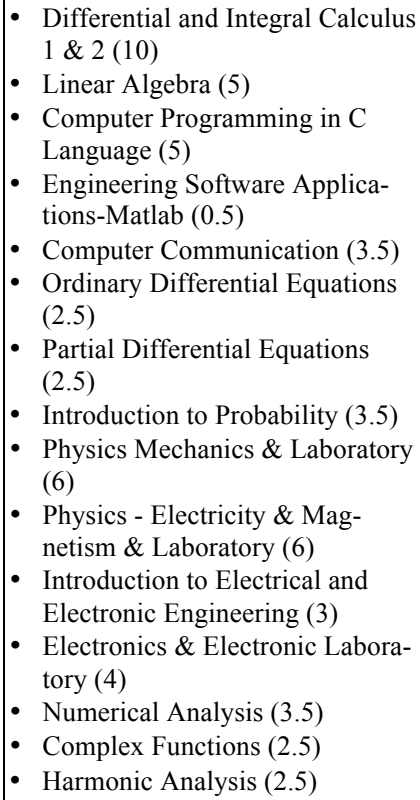 & 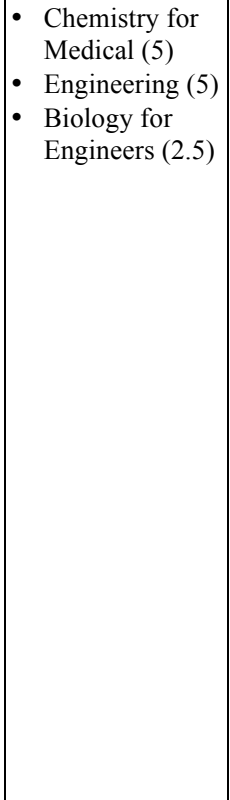 & $\begin{array}{l}\text { - Solid Mechanics and } \\
\text { its Medical Applica- } \\
\text { tions (3.5) } \\
\text { - Physiology for Engi- } \\
\text { neers (3) } \\
\text { - Physiology and Sys- } \\
\text { tems Control in the } \\
\text { Human Body (2.5) } \\
\text { - Thermodynamics and } \\
\text { Heat Transfer (3.5) } \\
\text { - Fluid Mechanics (3.5) } \\
\text { - Physiological Mechan- } \\
\text { ics of the Musculoskel- } \\
\text { etal System (3) }\end{array}$ & $\begin{array}{l}\text { - } \text { Medical Sensors (2.5) } \\
\text { - } \text { Imadiation in Medicine: } \\
\text { - Digital Signal Processing } \\
\text { (DSP) (2.5) } \\
\text { - Digital Systems in Medi- } \\
\text { cine (2.5) } \\
\text { - Image Processing(2.5) } \\
\text { - Algorithms and Data } \\
\text { - Structures (3) } \\
\text { Database and Data- } \\
\text { - Harehouse Systems (3.5) } \\
\text { Heat Transfer and Flow } \\
\text { - } 3 \text { Information Systems } \\
\text { Analysis(4) } \\
\text { Health information Sys- } \\
\text { tems and Data Security (3) } \\
\text { Decision Support Systems } \\
\text { and Health Record Sys- } \\
\text { tems (3.5) }\end{array}$ & $\begin{array}{l}\text { Clinical Engineer- } \\
\text { ing and Health } \\
\text { Technology Man- } \\
\text { agement (2) } \\
\text { - Medical Ethics (2) }\end{array}$ \\
\hline $\begin{array}{c}\text { Ad- } \\
\text { vance }\end{array}$ & $\begin{array}{l}\text { - Wave Theory for Medical Engi- } \\
\text { neering (2.5) } \\
\text { - Modern Physics for Medical } \\
\text { Engineering (3.5) } \\
\text { - Linear Systems and Control } \\
\text { Theory (2.5) } \\
\text { - Computer Embedded System } \\
\text { Process Control (2.5) }\end{array}$ & \begin{tabular}{|l} 
- \\
nedical Engi- \\
neering Labora- \\
tory (2) \\
- General and \\
Systemic Pa- \\
thology (2) \\
- Introduction for \\
Tissue Engi- \\
neering (2)
\end{tabular} & $\begin{array}{l}\text { Heat and Mass Trans- } \\
\text { fer in Biological Sys- } \\
\text { tems (2.5) } \\
\text { - Computational Meth- } \\
\text { ods in Engineering } \\
\text { - Advanced Flow and its } \\
\text { Medical Applications } \\
\text { (2.5) } \\
\text { - Material for Medical } \\
\text { Engineering and Im- } \\
\text { plants (2.5) } \\
\text { Medical Mechanics } \\
\text { Laboratory }\end{array}$ & $\begin{array}{l}\text { Decision Support Systems } \\
\text { and Health Record Sys- } \\
\text { tems (3.5) } \\
\text { - TeleMedicine (2) } \\
\text { - Advanced Signal Pro- } \\
\text { cessing and its Medical } \\
\text { Application (2.5) } \\
\text { - Advanced Image Pro- } \\
\text { cessing and its Medical } \\
\text { Applications (2.5) }\end{array}$ & $\begin{array}{ll}\text { - } & \text { Clinical Trails (2.5) } \\
\text { - } & \text { Medical Quality } \\
& \text { Assurance and Risk } \\
& \text { Management (2) } \\
\text { - } & \text { Medical Engineer- } \\
& \text { ing Laws (2) }\end{array}$ \\
\hline & & $\begin{array}{ll}\text { - } & \mathrm{E} \\
\text { - } & \mathrm{Fi}\end{array}$ & $\begin{array}{l}\text { ninar (2) } \\
\text { osure to the Medical In } \\
\text { al Project ( } 8)\end{array}$ & try and Medical Centers (2) & \\
\hline
\end{tabular}

and Medical Centers"). The spiral approach facilitates comprehensive teaching of three fields of specialization (MPS, DSPIP, and CE) as well as the linkage among them (Fig. 2).

Adoption of the spiral approach as a guideline for constructing an academic curriculum is compatible with other reported educational methods in the field of biomedical engineering [2]. According to these methods, courses that encourage self-learning using home projects and routine feedback discussions in class enhance students' achievements. Such interactions receive particular emphasis during students' final projects, wherein students present the progress of their projects and receive constructive feedback from classmates. This interactive approach is supported by previous studies that have concluded that peer interaction contributes towards inculcating thinking skills [16].

The curriculum structures particularly integrates well with the methods that support active leaning, such as PBL and CDIO [3], [5], [9]. In ME department at Afeka college, the PBL method is combined in varied courses such as "Material for Medical Engineering and Implants" which was detailed above. Based on our experience, PBL has been shown as an efficient bridge to the gap between theory and practice. Thus, combined this method with the spiral approach is contributes to more effective selflearning skills.

Additionally, our experience indicates that active learning improves also the ability to deal with problems and challenges. This conclusion / insight is supported by previous studies in engineering pedagogy [17].

Incorporation of English-language studies, for nonEnglish speakers, as an integral part of the curriculum was found to be an effective tool in ME training, an observation supported by previous educational reports [15]. Students in the ME program at Afeka are exposed to Englishlanguage content beginning from their first year. Initially, students are taught medical and engineering terminologies, and they proceed to deal with complex English-language content, such as professional literature. In advanced stages of the program, students are required to write reports and assignments in English. Incorporation of English training into $\mathrm{ME}$ education aligns with the target skills and the required future professional tasks of ME graduates. 
In the spirit of the spiral approach, in the curriculum detailed in this manuscript, tasks that students are assigned, particularly in laboratory courses, educational visits and the final project, are linked to knowledge acquired in previous courses and are providing engineering experience. Student assessments have already been found to contribute to improving engineering skills in an authentic work environment [18], [19]. The results of the survey also clearly indicate that the students themselves recognize the contribution of the approach to their academic and professional skills. Graduates' and employers' assessment surveys are attained each year by the employment advisory internal division. According do these surveys, employers also appreciate the benefits of our training and recruit new graduates yearly.

In contrast to the traditional method of learning material gradually, drawing solely from existing knowledge, the spiral approach challenges students with new and complex knowledge at the outset. According to this approach, comprehensive knowledge and understanding are attained throughout the years of study.

\section{CONCLUSION}

Based on our experiment, we conclude that ME educational curriculum, which adopted the spiral approach, could train medical engineers to have broad knowledge, creative thinking and a holistic perspective. Furthermore, implementing this approach would contribute to an environment that challenges both students and lecturers. Similar to other programs, here also, the cooperation of the academic staff contributes achieving the goals of the program [19], [20]. By doing so, an ME program would achieve the vision of training engineers who will be able to provide technological solutions to medical problems, and who will integrate well into the ME industry as well as into the academy. This manuscript could contribute for anyone who develops or improves curriculum, particularly in a multidisciplinary program.

The authors declare that they have no conflict of interest.

\section{REFERENCES}

[1] Weed, H. R. (1975). Biomedical engineering-practice or research? IEEE Transactions on Biomedical Engineering, 2(BME-22), 110114. http://dx.doi.org/10.1109/TBME.1975.324428

[2] Enderle, J. D., \& Bronzino, J. D. (2012). Introduction to biomedical engineering. Academic press.

[3] Perrenet, J. C., Bouhuijs, P. A. J., \& Smits, J. G. M. M. (2000) The suitability of problem-based learning for engineering education: theory and practice. Teaching in higher education, 5(3), 345358. http://dx.doi.org/10.1080/713699144

[4] Van der Hulst, M., \& Jansen, E. (2002). Effects of curriculum organisation on study progress in engineering studies. Higher Education, 43(4), http://dx.doi.org/10.1023/A:1015207706917

[5] Crawley, E., Malmqvist, J., Ostlund, S., \& Brodeur, D. (2007) Rethinking engineering education. In The CDIO Approach: Springer Singapore.

[6] Linder, B., \& Flowers, W. C. (2001). Integrating engineering science and design: a definition and discussion. International Journal of Engineering Education, 17(4/5), 436-439.

[7] Froyd, J. E., \& Ohland, M. W. (2005). Integrated engineering curricula. Journal of Engineering Education, 94(1), 147-164. http://dx.doi.org/10.1002/j.2168-9830.2005.tb00835.x

[8] Edström, K., Gunnarsson, S., \& Gustafsson, G. (2007). Integrated Curriculum Design. In Rethinking Engineering Education (pp. 77101). Springer US. http://dx.doi.org/10.1007/978-0-387-38290-6 4

[9] Fai, S. K., “An Observational Study of Infusing Design Thinking
[10] into the CDIO framework", Proceedings of 7th International CDIO Conference, June 20 - 23, 2011.

[11] Bruner, J. S. (1960). The process of education. Harvard University Press.

[12] Shneiderman, B. (1977). Teaching programming: A spiral approach to syntax and semantics. Computers \& Education, 1(4), 193-197. http://dx.doi.org/10.1016/0360-1315(77)90008-2

[13] Harden, R. M., \& Stamper, N. (1999). What Is a Spiral Curriculum?. Medical Teacher, 21(2), 141-43. http://dx.doi.org/10.1080/01421599979752

[14] Gattie, D. K., Kellam, N. N., Schramski, J. R., \& Walther, J. (2011). Engineering education as a complex system. European Journal of Engineering Education, 36(6), 521-535. http://dx.doi.org/10.1080/03043797.2011.622038

[15] Council for Higher Education in Israel. http://che.org.i1/en/?place=afeka-the-academic-college-ofengineering-in-tel-aviv-2

[16] Tatzl, D., \& Messnarz, B. (2013). Testing foreign language impact on engineering students' scientific problem-solving performance. European Journal of Engineering Education, 38(6), 620-630. http://dx.doi.org/10.1080/03043797.2012.719001

[17] Anderson, T., \& Soden, R. (2001). Peer interaction and the learning of critical thinking skills. Psychology Learning \& Teaching, 1(1), 37-40. http://dx.doi.org/10.2304/plat.2001.1.1.37

[18] Lucas, B., \& Hanson, J. (2016). Thinking Like an Engineer: Using Engineering Habits of Mind and Signature Pedagogies to Redesign Engineering Education. International Journal of Engineering Pedagogy (iJEP), 6(2), 4-13. http://dx.doi.org/10.3991/ijep.v6i2.5366

[19] Myllymäki, S. (2013). Incorporation of continuous student assessment into lectures in engineering education. European Journal of Engineering $\quad$ Education, 38(4), 385-393. http://dx.doi.org/10.1080/03043797.2013.780010

[20] Nikolic, S., Ritz, C., Vial, P. J., Ros, M., \& Stirling, D. (2015). Decoding Student Satisfaction: How to Manage and Improve the Laboratory Experience. Education, IEEE Transactions on, 58(3), 151-158. http://dx.doi.org/10.1109/TE.2014.2346474

[21] Ercan, M. F. (2013). Integration in Engineering Education: A Trial Run. International Journal of Engineering Pedagogy, 3(3), 61-66. http://dx.doi.org/10.3991/ijep.v3i3.2250

\section{AUTHORS}

Zehava Ovadia-Blechman is a senior lecturer and a researcher in the Medical Engineering Department at AfekaTel-Aviv Academic College of Engineering, Israel, and she is a member of the professional Medical Engineering Committee at the Israeli National Council of Higher Education. She also a member of Scientific Committee of the Israel Society for Medical and Biological Engineering (ISMBE). Dr. Ovadia-Blechman established the Medical Engineering Department at Afeka College, and was the first department head. She was a member of the College Educational Committee for over eight years. She is also a member of the Medical Engineering Department's Educational Committee.-(zehava@afeka.ac.il).

Ido Muller is a research and development medical engineer at the institute of endocrinology and diabetes at Schneider Children's Medical Center, Israel- He received his B.Sc. in Medical Engineering at Afeka - Tel-Aviv Academic College of Engineering. He was a research assistant at Afeka College and investigated the integration of the spiral approach in a medical engineering curriculum (idomuller@gmail.com).

Sara Naftali is a Senior Lecturer and a researcher in the Medical Engineering and the Software Engineering Departments of Afeka - Tel-Aviv Academic College of Engineering, Israel, where she established Afeka's program for outstanding students. She is also a member of the Medical Engineering Department's Educational Committee and the college Teaching Quality. (SaraN@afeka.ac.il).

Submitted 09 April 2016. Published as resubmitted by the authors 13 June 2016. 